\title{
Adjustment to Target Capital Structure and Global Financial Crisis: Evidence from Turkey
}

\author{
Yilmaz Yildiz
}

Abstract: The aim of this study is to investigate the adjustment speed towards target capital structures of the publicly-traded firms in Turkey for the period 2003-2016. To observe the impact of the 2007-2009 global financial crisis on the adjustment speed, additional estimations for the sub-periods are also employed. Consistent with the dynamic trade-off theory, Turkish firms adjust their capital structures to reach the target but the adjustment speed is relatively slow. The findings reveal that firms tend to close the gap between their current and target level of leverage by approximately $12 \%-14 \%$, each year. However, the adjustment speed is significantly lower for the post-crisis period (9\% - 10\%) than the crisis and pre-crisis periods (14\%-16\%). Additional findings also show that over-levered firms tend to adjust their capital structures more quickly than the under-levered firms. The findings are robust to different methods of estimations and also different considerations of the time periods.
Keywords: Speed of Adjustment; Dynamic Capital Structure; Trade-off Theory; Financial Crisis; Turkey

JEL: C23, G3, G32

$\begin{array}{ll}\text { Received } & : 05 \text { March } 2018 \\ \text { Revised } & : \text { 14 May } 2018 \\ \text { Accepted } & : \text { 21 June } 2018 \\ \text { Type } & \text { : Research }\end{array}$

\section{Introduction}

Since the seminal study of Modigliani and Miller (1958) which proposes the value of the firm is independent from its capital structure choices under the assumption of perfect capital markets, determinants of capital structure and target adjustment behavior of corporations have been attained widespread attention all over the world. Under the presence of market imperfections such as corporate and personal taxes, agency and bankruptcy costs, it is suggested that firms have a target capital structure which maximizes the value of the company (see, e.g., Modigliani \& Miller, 1963; Kraus \& Litzenberger, 1973; Miller, 1977; Titman, 1984). On the other hand, market imperfections such as adjustment costs may prevent firms to adjust their capital structures towards their target levels (Myers, 1984).

The discussion on the target adjustment behavior of firms is dominated by the two main approaches, namely trade-off and pecking order theories. According to the trade-off theory, firms able to maximize their value when the associated benefits of debt such as tax shield and disciplinary role of debt are equal to the marginal costs of debt such as financial distress, bankruptcy, and agency costs. Therefore, firms should take actions to reach their target and reduce the deviations from the optimal level which maximizes their value (Flannary \& Rangan, 2006). In other words, firms use larger portion of debt if they incur low level of bankruptcy costs and lower tax advantages. On the other hand, pecking order theory suggests that firms do not have any target capital structure instead managers prefer internal financing to external financing and debt financing to equity financing due to asymmetric information between insiders and outsiders (Myers, 
1984; Myers \& Majluf, 1984). Therefore, borrowing or issuing debt is a consequence of external financing needs rather than attempting to reach to the target capital structure. In other words, firm value is not a function of capital structure choices and firms do not follow a strategy which attempts to reach an optimal level.

Several papers have contributed to the above mentioned discussion by providing extensive evidence on whether trade-off or pecking-order theory explains the corporate capital structure policies of the corporations. Majority of these papers provide evidence in favor of the trade-off theory (Ozkan, 2001; Flannary \& Rangan, 2006; Kayhan \& Titman, 2007; Harford, Klasa, \& Walcott 2009; Ovtchinnikov, 2010; Oztekin \& Flannery, 2012). The evidence suggests that firms have target capital structures and they tend to adjust their capital structure to reach the target level. However, adjustment speed changes according to the firm-specific, country-specific and also macroeconomic factors. In contrast to the trade-off theory, ShyamSundera and Myers (1999) suggest that the explanatory power of pecking-order theory is greater than the trade-off theory. Consistent with this argument, Denis and Mckeon (2012) argue that capital structure of the firms is determined by the firms' financial surplus. Firms with a financial deficit tend to increase their debt level even though they are above their target levels. There is also indirect evidence which contradicts to the target capital structure argument. Masulis (1980) and Smith (1986) find that market reacts positively (negatively) to the increases (decreases) in financial leverage which is not consistent with the value maximization characteristic of optimal debt financing. Additionally, Hovakimian (2004) provides evidence of only weaker form of trade-off hypothesis. In Turkey, Arioglu and Tuan (2014) investigate the speed of adjustment toward the target capital structure of the listed firms in Borsa Istanbul for the period 1998-2010. Supporting the trade-off theory, their findings suggest that publicly traded firms in Turkey adjust their capital structure towards the target level and the speed of adjustment is about $29 \% .{ }^{1}$

Although it is well documented in the economics and finance literature that macroeconomic conditions have a strong effect on the corporate financial decisions, there are few number of studies which investigate the corporate capital structure decisions in different macroeconomic conditions. In one of the earlier studies, Korajczyk and Levy (2003) find that macroeconomic conditions have significant impact on the capital structure decisions especially for the unconstrained firms. They find that target capital structure is counter-cyclical for constrained firms but pro-cyclical for the unconstrained firms. Cook and Tang (2010) also investigate the impact of several macroeconomic factors on the speed of dynamic capital structure adjustments. They conclude that adjustment speed towards target capital structure is relatively faster in good macroeconomic conditions than in bad states of economy.

2007-2009 global financial crisis has a considerable impact on firm level investment and financial policies. The financial crisis started in the United States in the early 2007 and spread all over the world rapidly due to increasing integration among developed and developing markets and also presence of significant trade links between countries. Many emerging economies like Turkey have been affected through both direct and indirect channels. Due to changes in the dynamics of economies, markets, and corporations, it becomes indispensable to study how changes in the macroeconomic conditions affect the financial decisions and strategies of the firms. Due to increase in the risk perception and uncertainty during the crisis, it is expected that both lenders and borrowers will be more cautious than before which is expected to increase the cost of borrowing and in turn decrease the debt usage of the firms. Increasing uncertainty during 2007-2009 period may offset the advantages of debt financing over other types of financing. Given that global financial crisis has a considerable impact on the debt financing, it is expected that the capital adjustment behavior of the firms may vary according to the state of the economy. In other words, changing macroeconomic conditions is expected to affect the determinants of capital structure as well as the target adjustment behavior since the cost of adjustment and cost of being away from target have also changed. In a more recent paper, Demirguc-Kunt, Martinez Peria, and Tressel (2015) provide extensive evidence on the impact of global financial crisis on the firms' capital structures using a dataset of 79 countries. They find that financial crisis has a strong impact on the firm leverage and debt maturity. Firm leverage ratios decreased significantly aftermath of the financial crisis but this reduction is particularly significant for the small and private firms. On the other hand, there is no significant impact of financial crisis on the capital structure of the large and 
publicly listed firms. In general, they suggest that financial crisis increases the uncertainty and default risk which also increases the cost of borrowing since lenders demand greater risk premium. This in turn makes the borrowing less attractive for the firms. Moreover, increasing uncertainty decreases the motivation of firms to engage in long-term contracts which shortens the debt maturity. The impact of financial crisis on the corporate financial decisions is not constrained to the capital structure issue. Song and Lee (2012) investigate the impact of Asian crisis on the cash holding decisions and find that crisis has a strong impact on the cash holding policies beyond the traditional firm-specific factors. Moreover, Campello, Graham, and Harvey (2000) find that firms tend to delay or cancel their investment plans when the economic conditions get worse.

In this study, the target capital structure adjustment behavior of publicly-traded firms in Turkey in different macroeconomic conditions, specifically for the pre- and post-crisis periods is investigated. Global financial crisis in 2007-2009 provides an important opportunity to observe how changing macroeconomic conditions affect the capital structure policies of Turkish firms. Using a large data set including 2569 firmyear observations from 2003 to 2016, the findings suggest that global financial crisis has a strong impact on the capital structure decisions of Turkish firms. For the pre-crisis periods the speed of adjustment to target is about $14 \%-16 \%$ whereas for the post-crisis period speed of adjustment decreases to approximately $9 \%$ $10 \%$. Moreover, the findings also reveal that adjustment speed is significantly higher for the firms with high level of leverage. The results are robust to different empirical models, various first- stage predictions of target capital structure as well as different considerations of the time periods.

This study contributes to the literature in different ways. First, it provides direct evidence on the impact of global financial crisis on the capital structure decisions which is often a neglected issue in the literature. Second, current study complements the findings of Korajczyk and Levy (2003), Cook and Tang (2010) and Demirguc-Kunt et al. (2015) by providing additional evidence on the impact of macroeconomic conditions on corporate financial policies for a different sample of firms in an emerging market where the dynamics of corporate financial policies are expected to be different than advanced markets. Moreover, the findings of this study also extends the results of Arioglu and Tuan (2014) by using a different time period and focusing on the impact of financial crisis.

Following the introduction, the variables used in this study are discussed in Section 2. Section 3 briefly explains the data. In Section 4, in addition to the empirical models used in the study, the main findings of the study, and robustness checks are also discussed. Finally, Section 5 concludes the paper.

\section{Determinants of Capital Structure}

Although the aim of this paper is to investigate the adjustment towards target capital structure, it is important to discuss which firm-specific characteristics have an impact on the determinants of capital structure and also target adjustment behavior. In this section the determinants of capital structure which are widely cited in the prior literature are discussed.

\subsection{Firm Size}

Although majority of the empirical studies suggest a positive relationship between firm size and leverage, the evidence is quite mixed. Since larger firms are well diversified and they are less prone to bankruptcy costs, a positive relationship between firm size and leverage is expected (Titman \& Wessels, 1988; Rajan \& Zingales, 1995). This positive relationship is supported by Frank \& Goyal (2003), Ozkan (2001), Sayilgan et al. (2006). On the other hand, Gupta (1969) and Fischer, Heinkel, and Zechner (1989) find a negative relationship between leverage and firm size. Finally, Roden and Lewellen (1995) and Karadeniz et al. (2009) do not find any impact of size on the capital structure decisions. Natural logarithm of total assets is used as a proxy for the firm size.

\subsection{Growth Opportunities}

Myers (1977) suggest that firms with greater growth opportunities tend to hold less debt since larger amount of debt will decrease the firm value by leading to sub-optimal investment choices. Titman and 
Wessels (1988) state that firms with greater growth opportunities face greater agency costs due to rich future investment opportunities. Moreover, the greater portion of the growth firms' assets are intangibles which are expected to fall sharply when the firm faces bankruptcy. Therefore, a negative relationship between growth opportunities and leverage is expected. Following other studies (Rajan \& Zingales, 1995; Ozkan, 2001), the ratio of book value of assets minus the book value of equity plus the market value of equity to the book value of total assets is used as a proxy for the growth opportunities.

\subsection{Non-debt Tax Shield}

One of the important advantages of debt financing is the tax-deductible nature of the interest expenses. However, some investments may generate non-debt tax benefit to the companies especially in the form of depreciation expenses. Therefore, non-debt tax shield is considered as a substitute for the tax shield generated by debt financing, and in turn implies a negative relationship between non-debt tax shield and leverage (DeAngelo \& Masulis, 1980; Ozkan, 2001). On the other hand, high depreciation expense is an indication of larger intangible assets which may also imply lower growth opportunities (Krishnaswami, Spindt, \& Subramaniam, 1999; Ozkan, 2001). Therefore, in contrast to the previous argument, a positive relationship between non-debt tax shield and leverage may be implied. The ratio of depreciation expenses to the total assets is used as a proxy for the non-debt tax shield.

\subsection{Profitability}

According to the pecking order theory (Myers, 1984), firms prefer retained earnings over debt and debt over equity financing. Therefore, firms with higher levels of retained earnings will hold less debt. In other words, pecking order theory implies a negative relationship between profitability and leverage. Previous evidence supports this prediction (Titman \& Wessels, 1988; Rajan \& Zingales, 1995; Gaud, Jani, Hoesli, \& Bender, 2005; Karadeniz et al. 2009). On the other hand, high profitability is expected to increase the importance of tax shield generated by debt financing. Therefore, in contrast to the proposition of pecking order theory, a positive relationship between profitability and leverage is expected. The ratio of earnings before interest, taxes, and depreciation (EBITDA) to total assets is used as a proxy for profitability.

\subsection{Liquidity}

Another important firm characteristic which has an impact on the capital structure decisions is the liquidity of the company. The prediction about the impact of liquidity on capital structure is twofold. On one hand, firms with higher levels of liquid assets are able to meet short-term liabilities which may also increase their incentive to hold greater portion of debt (Ozkan, 2001). On the other hand, firms may use their current assets to finance their investments which in turn decrease their motivation of holding greater portion of debt. The ratio of current assets to current liabilities is used as a proxy for firm liquidity.

\subsection{Tangibility}

Similar to the discussion about the liquidity, tangibility of the firm has some important implications in terms of the capital structure decisions. However, the predictions about the relationship between tangibility and leverage are not clear cut. Bradley, Jarrell, and Kim (1984) suggest that greater tangibility increases the usage of debt since firms use their tangible assets as collaterals which in turn decrease the cost of borrowing and increase their leverage. Collaterals are expected to be more valuable particularly in the emerging markets where investor protections are low and bankruptcy risk is high (La Porta, Lopez-de-Silanes, Shleifer, \& Vishny, 1998). Moreover, firms which are not able to use their assets as collaterals prefer to issue equity rather than debt to finance their investments which implies a positive relationship between tangibility and leverage. On the contrary, usage of fixed assets for financing needs may increase the variability in future profits, increase the business risk which in turn have a negative impact on debt financing (Ferri \& Jones, 1979). The ratio of property, plant, and equipment to total assets is used as a proxy of tangibility. 


\subsection{R\&D Investments}

As a final determinant of capital structure, $R \& D$ investments are expected to have a negative impact on the debt financing. Similar to the arguments discussed in growth opportunities and tangibility, firms which make greater R\&D investments which are a portion of intangible assets, are expected to hold less debt due to unavailability of collaterals and future uncertainty related to their business operations (Flannary \& Rangan, 2006). As a measure of R\&D investment, a dummy variable equals to 1 if firm makes any R\&D investments and 0 , otherwise is used.

\section{Data Overview}

The adjustment to target capital structure behavior of the firms listed in Borsa Istanbul from 2003 to 2016 is examined. The reason for starting from 2003 is to avoid the impact of 2001 crisis. Any observation from 2002 is not included since lagged values are used in the estimations which may bias the results. ${ }^{2}$ The financial firms are also excluded from the sample since their most of the firm-specific characteristics is not comparable with the non-financial firms. Moreover, any observation which has any missing data for any of the dependent and explanatory variables is also dropped from the sample. The data is obtained from the Datastream. The final dataset includes 234 firms and 2569 firm-year observations.

Table 1. Variable Definitions

\begin{tabular}{|c|c|}
\hline Lev & Total debt divided by total assets \\
\hline Size & Natural logarithm of total assets \\
\hline Growth & $\begin{array}{l}\text { Book value of assets minus book value of equity plus market value of equity } \\
\text { divided by book value of assets }\end{array}$ \\
\hline Non-debt tax shield & Total depreciation expenses divided by total assets \\
\hline Profitability & Earnings before interest and taxes plus depreciation divided by total assets \\
\hline Liquidity & Current assets divided by current liabilities \\
\hline Tangibility & Fixed assets divided by total assets \\
\hline$R \& D$ & $\begin{array}{l}\text { Dummy variable equals to } 1 \text { if firm makes any R\&D investments in a given } \\
\text { year }\end{array}$ \\
\hline Post & $\begin{array}{l}\text { Dummy variable equals to } 1 \text { if the observations belongs to the year from } 2010 \\
\text { to } 2016 \text { and } 0 \text {, otherwise }\end{array}$ \\
\hline
\end{tabular}

Following Ozkan (2001) and Gaud et al. (2005) the ratio of total debt to total assets (Lev) is used as a proxy for the leverage. The definitions and summary statistics of the variables used in this study is presented in Table 1 and Table 2, respectively. The mean (median) value of leverage (Lev) is about 23\% and 19\%, respectively.

Table 2. Descriptive Statistics

\begin{tabular}{|c|c|c|c|c|c|}
\hline & Mean & Std. dev. & $\mathrm{P} 25$ & P50 & P75 \\
\hline LeV $_{t}$ & 0.229 & 0.211 & 0.050 & 0.186 & 0.358 \\
\hline Size $_{t-1}$ & 12.563 & 1.658 & 11.355 & 12.402 & 13.607 \\
\hline Growth $_{\mathrm{t}-1}$ & 1.394 & 0.982 & 0.901 & 1.122 & 1.517 \\
\hline Non-debt tax shield $d_{t-1}$ & 0.038 & 0.028 & 0.019 & 0.033 & 0.049 \\
\hline Profitabilityt-1 & 0.110 & 0.117 & 0.045 & 0.101 & 0.166 \\
\hline Liquidity $_{\mathrm{t}-1}$ & 2.187 & 2.195 & 1.074 & 1.529 & 2.341 \\
\hline Tangibilityt-1 & 0.356 & 0.2112 & 0.193 & 0.346 & 0.499 \\
\hline$R \& D_{t-1}$ & 0.423 & 0.494 & 0 & 0 & 1 \\
\hline
\end{tabular}


Notes: This table presents the descriptive statistics of the variables used in this study. Variable definitions are presented in Table

1. P25, P50, and P75 denote the $25^{\text {th }}, 50^{\text {th }}$, and $75^{\text {th }}$ percentiles.

As it is evident in the prior literature (Demirguc-Kunt et al., 2015), debt ratios of firms are not stable over time. More importantly, 2007-2009 global financial crisis has made considerable impact of capital structures of firms all over the world. Table 3, presents the pattern of leverage ratios over time for the sample firms. As it is seen in Table 3, leverage ratios of Turkish firms have considerably increased after the global financial crisis. Mean leverage ratio during the pre-crisis period (2003-2006) ranges from 0.17 to 0.20 . Leverage ratios has increased to about $23 \%-24 \%$ during the crisis period (2008-2009). Although there is a slight decrease in the debt financing in the first year (2010) after the financial crisis, this trend did not last too long. From 2013 to 2015, the mean value of leverage is around 26\%. In 2016, average debt ratio has risen to approximately $29 \%$. This figure shows that publicly listed firms in Turkey tend to increase their leverage aftermath of the global financial crisis.

Table 3. Leverage ratios over years

\begin{tabular}{lll}
\hline & Mean & Median \\
\hline 2003 & 0.203 & 0.151 \\
2004 & 0.172 & 0.122 \\
2005 & 0.175 & 0.128 \\
2006 & 0.191 & 0.146 \\
2007 & 0.189 & 0.129 \\
2008 & 0.239 & 0.184 \\
2009 & 0.224 & 0.186 \\
2010 & 0.219 & 0.191 \\
2011 & 0.236 & 0.192 \\
2012 & 0.229 & 0.200 \\
2013 & 0.261 & 0.238 \\
2014 & 0.253 & 0.228 \\
2015 & 0.264 & 0.257 \\
2016 & 0.293 & 0.280 \\
Total & 0.229 & 0.186 \\
\hline Notes: This table presents the mean and median leverage ratios of the \\
sample firms over years.
\end{tabular}

\section{Model Specification and Empirical Analysis}

\subsection{Target Capital Structure}

To predict the adjustment speed to target capital structure, two-step process is employed. The analysis starts with regressing the leverage with the explanatory variables which are extensively used in the literature and also discussed in Section 2 and 3. Then, after running the first stage regressions, the target leverage ratios are predicted for each firm-year observation. The first stage equation is expressed as follow:

$$
\operatorname{Lev}_{i, t}^{*}=\beta X_{i, t-1}
$$

In equation (1) $L e v_{i, t}^{*}$ corresponds to the estimated target leverage for firm $i$ and time $t . X_{i, t-1}$ is the vector of explanatory variables for firm $i$ in time $t-1$ and $\beta$ is the vector of coefficients. Lagged values of explanatory variables are used instead of current values to partially avoid endogeneity. There are several ways to estimate the determinants of capital structure and target leverage ratios. As a first step, two different estimations to predict the target leverage ratio are employed. First one is the ordinary least square (OLS) estimation which also controls for year and industry fixed effects. As a second method, the target leverage ratio is predicted for each firm-year observation using two-stage regression of Fama and Macbeth (1973) 
which depends on the cross-sectional estimations of leverage for each year. First stage estimation results of leverage are presented in Table 4.

Table 4. First Stage Estimations of Capital Structure

\begin{tabular}{|c|c|c|}
\hline & $\begin{array}{l}\text { (1) } \\
\text { OLS }\end{array}$ & $\begin{array}{l}(2) \\
\text { Fama-Macbeth }\end{array}$ \\
\hline Size $_{t-1}$ & $\begin{array}{l}0.004 \\
(0.003)\end{array}$ & $\begin{array}{l}0.002 \\
(0.003)\end{array}$ \\
\hline Growth $_{\mathrm{t}-1}$ & $\begin{array}{l}0.025 * * * \\
(0.007)\end{array}$ & $\begin{array}{l}0.032^{* * *} \\
(0.008)\end{array}$ \\
\hline Non-debt tax shield $d_{t-1}$ & $\begin{array}{l}0.440 * * \\
(0.188)\end{array}$ & $\begin{array}{l}0.599 * * \\
(0.273)\end{array}$ \\
\hline Profitabilityt-1 & $\begin{array}{l}-0.223^{* * *} \\
(0.054)\end{array}$ & $\begin{array}{l}-0.194^{* *} \\
(0.072)\end{array}$ \\
\hline Liquidityt-1 $_{\mathrm{t}}$ & $\begin{array}{l}-0.036 * * * \\
(0.002)\end{array}$ & $\begin{array}{l}-0.036^{* * *} \\
(0.002)\end{array}$ \\
\hline Tangibilityt-1 & $\begin{array}{l}-0.040 * \\
(0.023)\end{array}$ & $\begin{array}{l}-0.023 \\
(0.022)\end{array}$ \\
\hline$R \& D_{t-1}$ & $\begin{array}{l}0.021^{* *} \\
(0.008)\end{array}$ & $\begin{array}{l}0.020^{* * *} \\
(0.003)\end{array}$ \\
\hline Constant & $\begin{array}{l}0.283 * * * \\
(0.045)\end{array}$ & $\begin{array}{l}0.327^{* * *} \\
(0.039)\end{array}$ \\
\hline Year fixed & Yes & No \\
\hline Industry fixed & Yes & Yes \\
\hline $\mathrm{R}^{2}$ & 0.240 & 0.284 \\
\hline \# of observations & 2569 & 2569 \\
\hline
\end{tabular}

Notes: This table presents the estimation results of leverage. Variable definitions are presented in Table $1 . * * * * *$, and $*$ denote the significance level at $1 \%, 5 \%$, and $10 \%$.

Before moving on to the adjustment to target capital structure estimations, it is useful to discuss on the determinants of capital structure. First of all, majority of the explanatory variables are significant in both of the estimations. The impact of growth opportunities, non-debt tax shield, and R\&D expenses on capital structure is positive and significant which implies that firms with greater growth opportunities, non-debt tax shield and also R\&D expenses tend to hold larger amount of debt. On the other hand, profitability and liquidity have a negative effect on the debt financing. Size has a positive coefficient but does not exert any significance on capital structure decisions. Finally, the relationship between tangibility and leverage is not too strong.

\subsection{Adjustment to Target Capital Structure}

Prior studies have suggested several ways to estimate the adjustment speed towards the target leverage (e.g. Ozkan, 2001; Gaud et al., 2005; Oztekin \& Flannery, 2012). In this study, the procedure of Byoun (2008) which suggests estimating the target capital structure in the first stage (Equation 1) and then regressing the change in leverage ratio during a year with the deviation from the target at the beginning of the year, is employed (Equation 2). The main advantage of this approach is to include interactive effects of the variables into the model. As a robustness check, the target adjustment speed is also estimated by Blundell and Bond (1998) dynamic GMM (generalized method of moments) which will be discussed in Section 4.3. The main target adjustment equation is as follows:

$$
L e v_{i, t}-\operatorname{Lev}_{i, t-1}=\lambda\left(\operatorname{Lev}_{i, t}^{*}-\operatorname{Lev}_{i, t-1}\right)+\varepsilon_{i, t}
$$


The left hand side of the Equation (2) expresses the change in leverage from year $t-1$ to $t$. $L e v_{i, t}^{*}-$ $L e v_{i, t-1}$ is the deviation from the target at the beginning of the year $t$ and $L e v_{i, t}^{*}$ is the target leverage which is estimated in the first stage by using OLS or Fama-Macbeth regressions which are discussed before (Equation 1). As the primary coefficient of interest, $\lambda$ denotes the adjustment speed to the target capital structure.

In Table 5, the results for adjustment speed estimations are presented. It should be noted that there are two different first stage estimations. Moreover, the whole sample is divided into two as 2003-2009 and 2010-2016 to see how speed of adjustment to target leverage changes after the global financial crisis. The coefficient of $L e v_{i, t}^{*}-L e v_{i, t-1}$ in Table 5 is about 0.125 for the whole sample period which means that the estimated adjustment speed to target leverage is about $12.5 \%$ in each year. This implies that firms in Turkey have target capital structures in consistent with the trade-off theory but the adjustment speed is relatively lower than the advanced markets ${ }^{3}$ which also suggests the cost of deviating from the target is low for Turkish firms or the cost of adjustment is too high. In Turkey Arioglu and Tuan (2014) suggest approximately $29 \%$ adjustment speed which is greater than current prediction. The difference between the coefficients may be arisen from the different time periods employed in the study of Arioglu and Tuan (2014). However, the predicted adjustment speed in this study is in line with the results of other studies which focus on the developing or transition economies. For example, Haas and Peters (2006) suggest that transition economies in Europe close approximately $12 \%$ of the gap between target and actual leverage. In other words, it takes 5.5 years to close the gap between actual and desired capital structures. Different adjustment speeds for different countries also support the propositions of Oztekin and Flannery (2012). They suggest that countryspecific factors especially legal and traditional characteristics of countries significantly affect the target adjustment speeds in firm level.

Table 5. Adjustment Speed for Capital Structure

\begin{tabular}{|c|c|c|c|}
\hline \multicolumn{4}{|c|}{ Panel A. First stage is based on OLS regression } \\
\hline & \multicolumn{3}{|c|}{ Dependent variable: Lev $_{t}-$ Lev $_{t-1}$} \\
\hline & $2003-2015$ & $2003-2009$ & $2010-2016$ \\
\hline \multicolumn{4}{|l|}{ Deviation from target: } \\
\hline \multirow[t]{2}{*}{$\operatorname{Lev}_{t}^{*}-\operatorname{Lev}_{\mathrm{t}-1}$} & $0.126 * * *$ & $0.164 * * *$ & $0.098 * * *$ \\
\hline & $(0.013)$ & $(0.022)$ & $(0.015)$ \\
\hline \multirow[t]{2}{*}{ Constant } & $-0.050 * * *$ & $-0.075^{* * *}$ & 0.016 \\
\hline & $(0.016)$ & $(0.021)$ & $(0.018)$ \\
\hline Year fixed & Yes & Yes & Yes \\
\hline Industry fixed & Yes & Yes & Yes \\
\hline$R^{2}$ & 0.116 & 0.184 & 0.061 \\
\hline $\mathrm{N}$ & 2569 & 1136 & 1433 \\
\hline \multicolumn{4}{|c|}{ Panel B. First stage is based on Fama-Macbeth regression } \\
\hline & \multicolumn{3}{|c|}{ Dependent variable: $\operatorname{Lev}_{\mathrm{t}}-\mathrm{Lev}_{\mathrm{t}-1}$} \\
\hline Deviation from target: & $2003-2015$ & 2003-2009 & $2010-2016$ \\
\hline \multirow[t]{2}{*}{$\operatorname{Lev}_{t}{ }^{*}-\operatorname{Lev}_{\mathrm{t}-1}$} & $0.125^{* * *}$ & $0.164 * * *$ & $0.097 * * *$ \\
\hline & $(0.013)$ & $(0.022)$ & $(0.015)$ \\
\hline \multirow[t]{2}{*}{ Constant } & $-0.054^{* * *}$ & $-0.080 * * *$ & 0.014 \\
\hline & 0.016 & $(0.021)$ & $(0.018)$ \\
\hline Year fixed & Yes & Yes & Yes \\
\hline Industry fixed & Yes & Yes & Yes \\
\hline$R^{2}$ & 0.116 & 0.184 & 0.060 \\
\hline $\mathrm{N}$ & 2569 & 1136 & 1433 \\
\hline
\end{tabular}


Note: This table presents the estimations of target capital structure adjustment speeds. In Panel A, target leverage ratio (Lev ${ }_{t}^{*}$ ) is estimated by using OLS regression. In Panel B, target leverage ratio $\left(\right.$ Lev $\left._{t}{ }^{*}\right)$ is estimated by using Fama-Macbeth two-step regression. Variable definitions are presented in Table $1 . * *,{ }^{* *}$, and $*$ denote the significance levels at $1 \%, 5 \%$ and $10 \%$, respectively.

To investigate the adjustment speed in different macroeconomic environments, the sample period is divided into two as 2003-2009 and 2010-2016. As it is presented in Table 5, adjustment speed is significantly lower aftermath of the financial crisis. For the period 2003 to 2009, target adjustment speed is about $16.4 \%$. However, adjustment speed decrease to about $10 \%$ after the global financial crisis. This finding imply that the cost of having sub-optimal capital structures is lower than the cost of adjustment during the post-crisis period. The findings are not sensitive to the different first stage regressions. Moreover, as a result of the significant changes in the financial reporting in 2005, additional tests are also employed by excluding the years before 2006. However, the results are qualitatively similar.

Next, the heterogeneity in the adjustment speed is investigated by including the interaction term of deviation from the target and a dummy variable equals to 1 if the firm is above target and 0 , otherwise. By doing so, it is possible to separately observe the adjustment behavior of the firms which are above or below the target. The regression estimation is as follows:

$$
\operatorname{Lev}_{i, t}-\operatorname{Lev}_{i, t-1}=\lambda\left(\operatorname{Lev}_{i, t}^{*}-\operatorname{Lev}_{i, t-1}\right)+\gamma_{1}\left(\operatorname{Lev}_{i, t}^{*}-\operatorname{Lev}_{i, t-1}\right) * \text { Above target }+\varepsilon_{i, t}
$$

In the Equation 3, Above target is a dummy variable equals to 1 if the firm is above the target and 0 , otherwise. A positive and significant value of $\gamma_{1}$ suggests that above-target firms adjust their capital structures to the target levels more quickly than the below-target firms.

Table 6. Heterogeneity on the Adjustment Speed for Capital Structure

\begin{tabular}{|c|c|c|}
\hline & First stage: OLS & First stage: Fama-Macbeth \\
\hline & \multicolumn{2}{|c|}{ Dependent variable: $\operatorname{Lev}_{t}-\operatorname{Lev}_{t-1}$} \\
\hline \multicolumn{3}{|l|}{ Deviation from target: } \\
\hline \multirow[t]{2}{*}{$\operatorname{Lev}_{\mathrm{t}}^{*}-\operatorname{Lev}_{\mathrm{t}-1}$} & $0.046 * *$ & $0.062 * *$ \\
\hline & $(0.022)$ & $(0.021)$ \\
\hline \multirow[t]{2}{*}{$\operatorname{Lev}_{\mathrm{t}}^{*}-$ LeV $_{\mathrm{t}-1} *$ Above target } & $0.130 * * *$ & $0.106^{* *}$ \\
\hline & $(0.040)$ & $(0.039)$ \\
\hline \multirow[t]{2}{*}{ Constant } & $-0.040 * *$ & -0.045 \\
\hline & $(0.017)$ & $(0.017)$ \\
\hline Year fixed & Yes & Yes \\
\hline Industry fixed & Yes & Yes \\
\hline $\mathrm{R}^{2}$ & 0.121 & 0.119 \\
\hline $\mathrm{N}$ & 2569 & 2569 \\
\hline
\end{tabular}

According to the estimation results presented in Table 6, there is a significant difference between the adjustment speeds of firms with above and below target. Positive and significant coefficient of $\gamma_{1}$ implies that firms which are above target tend to adjust their capital structure more quickly. Faster adjustment speeds of firms with high leverage suggest that cost of being away from target is significantly higher for these firms. On the other hand, firms tend to stay sub-optimal and increase their debt to reach the target level relatively slowly if they are well below their target level. Therefore, rather than trade-off theory, pecking order theory might be more valid to explain the adjustment behavior of firms which are below the desired level of leverage.

\subsection{Robustness Check - GMM Estimations for Capital Structure}


As it is discussed before, there are several ways to predict the firms' adjustment speed to target capital structures. As a robustness check, following Ozkan (2001), and Arioglu and Tuan (2014) the speed of adjustment is estimated by employing dynamic Blundell and Bond (1991) generalized method of moments $(\mathrm{GMM})^{4}$. The regression equation as follows ${ }^{5}$ :

$$
\operatorname{Lev}_{i, t}=\delta L e v_{i, t-1}+\beta X_{i, t-1}+\varepsilon_{i, t}
$$

In equation (4) 1- $\delta$ denotes the speed of adjustment to target capital structure ${ }^{6}$. The results of GMMsystem estimations are presented in Table 7.

The GMM estimation results lead to the similar findings which are discussed before. The coefficient of the lagged dependent variable is about 0.86 (Panel 1 ) which implies approximately $14 \%$ of adjustment speed (1-0.86). To observe the impact of global financial crisis on the adjustment speed, in panel (2) the postcrisis dummy (Post) which equals to 1 if the observation is from the period 2010-2016 and also the interaction term of Post with the lagged dependent variable (Post* LeV $_{t-1}$ ) are included. The coefficient of the interaction term is positive and significant at $10 \%$ which means the adjustment speed is lower (approximately $9 \%$ ) in the post-crisis period. In addition to the coefficient and standard errors, the p-values of first (AR 1) and second (AR 2) order autocorrelation and also Hansen statistics are reported. Insignificant AR (2) satisfies the absence of second order correlation which is an important assumption of the generalized method of moments. Moreover, Sargan test of over-identification is also insignificant and suggests the validity of the instruments.

Table 7. Blundell-Bond Dynamic GMM Estimations of Capital Structure

\begin{tabular}{|c|c|c|}
\hline & (1) & (2) \\
\hline \multirow[t]{2}{*}{$\operatorname{Lev}_{\mathrm{t}-1}$} & $0.859 * * *$ & $0.868 * * *$ \\
\hline & $(0.026)$ & $(0.022)$ \\
\hline \multirow[t]{2}{*}{ Size $_{\mathrm{t}-1}$} & -0.000 & -0.001 \\
\hline & $(0.001)$ & $(0.001)$ \\
\hline \multirow{2}{*}{ Growth $_{\mathrm{t}-1}$} & -0.004 & -0.004 \\
\hline & (0.003) & (0.003) \\
\hline \multirow[t]{2}{*}{ Non-debt tax shield $\mathrm{t}_{-1}$} & 0.167 & 0.145 \\
\hline & $(0.114)$ & (0.109) \\
\hline \multirow[t]{2}{*}{ Profitability ${ }_{t-1}$} & $0.069 * * *$ & $0.076 * * *$ \\
\hline & $(0.026)$ & $(0.026)$ \\
\hline \multirow{2}{*}{ Liquidity $y_{t-1}$} & $-0.003 * * *$ & $-0.002 * *$ \\
\hline & $(0.001)$ & $(0.001)$ \\
\hline \multirow[t]{2}{*}{ Tangibility } & 0.001 & 0.003 \\
\hline & (0.017) & $(0.017)$ \\
\hline \multirow[t]{2}{*}{$R \& D_{t-1}$} & -0.000 & -0.001 \\
\hline & $(0.005)$ & $(0.005)$ \\
\hline \multirow[t]{2}{*}{ Post } & & $0.050 * * *$ \\
\hline & & $(0.012)$ \\
\hline \multirow[t]{2}{*}{ Post* Lev $_{\mathrm{t}-1}$} & & $0.042^{*}$ \\
\hline & & $(0.023)$ \\
\hline \multirow[t]{2}{*}{ Constant } & -0.024 & -0.023 \\
\hline & $(0.033)$ & $(0.031)$ \\
\hline Year fixed & Yes & Yes \\
\hline Industry fixed & Yes & Yes \\
\hline $\mathrm{AR}(1)$ & 0.000 & 0.000 \\
\hline$A R(2)$ & 0.815 & 0.765 \\
\hline Hansen & 0.307 & 0.323 \\
\hline \# of observations & 2569 & 2569 \\
\hline
\end{tabular}


Notes: This table presents the dynamic GMM-system estimation results of leverage. In both of the estimations, lagged dependent variable ( $\left.\operatorname{LeV}_{\mathrm{t}-1}\right)$ and Growth $_{\mathrm{t}-1}$ treated as endogenous and all available lags are used as instruments. Variable definitions are presented in Table $1 . * * *, * *$, and $*$ denote the significance level at $1 \%$, $5 \%$, and $10 \%$.

\subsection{Robustness Check - Alternative Specification of Target Leverage}

As discussed in Section 4.1, the target leverage is predicted by employing OLS and Fama-Macbeth regressions. As a robustness check, industry average of leverage is also used as a target at the firm-level $\left(L e v_{i, t}^{*}\right)$. More specifically, for each year the average industry leverage is calculated as a target for each firm and the deviation from target is computed by subtracting the actual leverage from the target leverage in a similar reasoning discussed before. The ICB (Industry Classification Benchmark) industry codes are used for industry classification. Table 8 presents the results.

Table 8. Adjustment Speed for Capital Structure - First Stage is Based on Industry Average

\begin{tabular}{|c|c|c|c|}
\hline \multicolumn{4}{|c|}{ First stage is based on industry average } \\
\hline & \multicolumn{3}{|c|}{ Dependent variable: $\mathrm{Lev}_{\mathrm{t}}-\mathrm{LeV}_{\mathrm{t}-1}$} \\
\hline & 2003-2015 & 2003-2009 & 2010-2016 \\
\hline \multicolumn{4}{|c|}{ Deviation from target: } \\
\hline \multirow[t]{2}{*}{$\operatorname{Lev}_{\mathrm{t}}{ }^{*}-\operatorname{LeV}_{\mathrm{t}-1}$} & $0.114^{* * *}$ & $0.145^{* * *}$ & $0.088 * * *$ \\
\hline & $(0.012)$ & $(0.021)$ & $(0.013)$ \\
\hline \multirow[t]{2}{*}{ Constant } & $-0.050 * * *$ & $-0.069 * * *$ & $0.012 * * *$ \\
\hline & $(0.016)$ & $(0.021)$ & $(0.017)$ \\
\hline Year fixed & Yes & Yes & Yes \\
\hline Industry fixed & Yes & Yes & Yes \\
\hline $\mathrm{R}^{2}$ & 0.117 & 0.179 & 0.063 \\
\hline $\mathrm{N}$ & 2569 & 1136 & 1433 \\
\hline
\end{tabular}

Notes: This table presents the estimations of target capital structure adjustment speed. Target leverage ratio $\left(\operatorname{Lev}_{t}{ }^{*}\right)$ is employed as the yearly industry averages of leverage. Variable definitions are presented in Table $1 . * * *, * *$, and $*$ denote the significance levels at $1 \%, 5 \%$ and $10 \%$, respectively.

The results are not sensitive to the first stage estimations. The estimated adjustment speed is about $11 \%$ for the whole sample period, $15 \%$ for the crisis and pre-crisis period and $9 \%$ for the post-crisis period. Consistent with the previous estimates, speed of adjustment to target leverage is significantly lower in the post-crisis period.

\subsection{Robustness Check - Different Time Periods}

Although the primary aim of this study is to explore how speed of adjustment to target capital changes after the global financial crisis, one may argue that the impact of pre-crisis and crisis periods on the speed of adjustment may be different. In other words, combining the pre-crisis and crisis periods may yield biased results due to different macroeconomic conditions. To avoid this concern, the sample is divided into several time-periods which enables to observe pattern in the speed of adjustment in shorter time periods. Four different time periods are formed as 2003-2006, 2007-2009, 2010-2012 and 2013-2016. The results for the sub-periods are presented in Table 9.

As it is seen in Table 9, speed of adjustment towards target capital structure consistently decreasing over time. For the period 2003-2006, adjustment speed is approximately $17.5 \%$ whereas it is approximately $12.2 \%$ for the period just after the global financial crisis (2010-2012). More importantly, speed of adjustment tends to be even lower (7.8\%) for the period 2013-2016. Therefore, it can be concluded that the primary results of this study holds even after considering different time periods. 
Table 9. Adjustment Speed for Capital Structure - Different Time Periods

\begin{tabular}{|c|c|c|c|c|}
\hline \multicolumn{5}{|c|}{ Panel A. First stage is based on OLS regression } \\
\hline & \multicolumn{4}{|c|}{ Dependent variable: $\mathrm{LeV}_{\mathrm{t}}-\mathrm{LeV}_{\mathrm{t}-1}$} \\
\hline & $2003-2006$ & $2007-2009$ & $2010-2012$ & $2013-2016$ \\
\hline \multicolumn{5}{|c|}{ Deviation from target: } \\
\hline \multirow[t]{2}{*}{$\operatorname{Lev}_{t}^{*}-\operatorname{Lev}_{\mathrm{t}-1}$} & $0.177^{* * *}$ & $0.143^{* * *}$ & $0.124^{* * *}$ & $0.077^{* * *}$ \\
\hline & $(0.032)$ & $(0.028)$ & $(0.024)$ & (0.019) \\
\hline \multirow[t]{2}{*}{ Constant } & $-0.095 * * *$ & -0.007 & 0.046 & 0.032 \\
\hline & $(0.032)$ & $(0.012)$ & $(0.029)$ & $(0.021)$ \\
\hline Year fixed & Yes & Yes & Yes & Yes \\
\hline Industry fixed & Yes & Yes & Yes & Yes \\
\hline $\mathrm{R}^{2}$ & 0.203 & 0.154 & 0.086 & 0.048 \\
\hline $\mathrm{N}$ & 580 & 556 & 617 & 816 \\
\hline \multicolumn{5}{|c|}{ Panel B. First stage is based on Fama-Macbeth regression } \\
\hline & \multicolumn{4}{|c|}{ Dependent variable: Lev $_{t}-\operatorname{Lev}_{\mathrm{t}-1}$} \\
\hline & $2003-2006$ & $2007-2009$ & $2010-2012$ & $2013-2016$ \\
\hline \multicolumn{5}{|c|}{ Deviation from target: } \\
\hline \multirow[t]{2}{*}{$\operatorname{Lev}_{t}^{*}-\operatorname{Lev}_{\mathrm{t}-1}$} & $0.175^{* * *}$ & $0.145^{* * *}$ & $0.122 * * *$ & $0.078 * * *$ \\
\hline & $(0.031)$ & $(0.027)$ & $(0.024)$ & (0.019) \\
\hline \multirow[t]{2}{*}{ Constant } & $-0.101^{* * *}$ & -0.012 & 0.044 & 0.033 \\
\hline & $(0.033)$ & 0.012 & (0.029) & $(0.021)$ \\
\hline Year fixed & Yes & Yes & Yes & Yes \\
\hline Industry fixed & Yes & Yes & Yes & Yes \\
\hline$R^{2}$ & 0.203 & 0.155 & 0.085 & 0.048 \\
\hline $\mathrm{N}$ & 580 & 556 & 617 & 816 \\
\hline
\end{tabular}

\section{Conclusion}

In this study the speed of adjustment to the target capital structure for the non-financial firms listed in Borsa İstanbul is investigated from 2003 to 2016. By employing a two-stage process in estimating the speed of adjustment, the results reveal that firms in Turkey close the gap between target and current capital structure by approximately 12\%-14\% each year. However, 2007-2009 global financial crisis has a considerable impact on the adjustment process. Adjustment speed is approximately $14 \%-16 \%$ for the period 2003-2009 whereas it decreases to $10 \%$ aftermath of the global financial crisis. In other words, firms tend to adjust their capital structure more slowly during the post-crisis period compared to the prior years. Moreover, the findings suggest that over-levered firms tend to adjust their capital structure more quickly than the underlevered firms. Our results are robust to different methods of estimations as well as different considerations of time periods.

Despite the ample evidence of the impact global financial crisis on the corporate financial policies, the role of financial crisis on the speed of adjustment to the target leverage is often neglected. Therefore, 
the findings of this study shed additional lights on how firms decide on their capital structure and how they react to the global financial crisis. The findings are also complement to those of Arioglu and Tuan (2014) which investigate the speed of adjustment to target capital structure for the period 1998 to 2010.

Current study is not without its limitations. First, some other firm-specific information such as governance or ownership characteristics of the firms are not included to the model due to unavailability of data. Second, it may be useful to investigate the impact of global financial crisis on the debt maturity. However, this issue is beyond the scope of this paper. Finally, further studies might investigate the impact of different factors such as financial constraints or financial flexibility of the firms on the adjustment process.

\section{End Notes}

1. In addition to the study of Arioglu and Tuan (2014), there are several studies which investigate the determinants of capital structure in Turkey (Ata \& Ag, 2010; Demirhan, 2009; Guler, 2010; Guner, 2016; Karadeniz, Kandir, Balcilar, \& Beyazit Onal, 2009; Koksal \& Orman, 2015; Sayilgan, Karabacak, \& Kucukkocaoglu, 2006).

2. Including the year 2002 in our estimations require using the data from 2001 (crisis year) since lagged explanatory variables are used in the estimation process. Because of this, the sample period starts from 2003.

3. The adjustment speed is 50\% for UK (Ozkan, 2001); 25\%-35\% for US (Flannary \& Rangan, 2006); 27\%-39\% for Asian firms (Getzmann et al., 2010).

4. Other than GMM estimations, using OLS or Least Square Dummy Variable (LSDV) estimations lead to dynamic panel bias since lagged dependent variable $\left(\right.$ Lev $\left._{i, t-1}\right)$ is endogeneous to fixed effects. To solve this problem Arellano and Bond (1991) and Blundell and Bond (1998) propose valid instruments for both lagged dependent variable and other endogenous variables which are uncorrelated with the fixed effects. GMM-system which is proposed by Blundell and Bond (1998) is preferred. Different than difference GMM which is proposed by Arellano and Bond (1991), GMMsystem instruments the levels with the past differences.

5. Equation 4 is a combination of Equation 1 and Equation 2.

6. See Ozkan (2001) for the detailed discussion on the dynamic estimation of capital structure.

\section{References}

Arellano, M., \& Bond, S. (1991). Some tests of specification for panel data: Monte Carlo evidence and an application to employment equations. The Review of Economic Studies, 58(2), 277-297.

Arioglu, E., \& Tuan, K. (2014). Speed of adjustment: Evidence from Borsa İstanbul. Borsa Istanbul Review, 14(2), 126131.

Ata, H. A., \& Ag, A. G. Y. (2010). Firma karakteristiğinin sermaye yapısı üzerindeki etkisinin analizi. Ekonometri ve istatistik, (11), 45-60.

Blundell, R., \& Bond, S. (1998). Initial conditions and moment restrictions in dynamic panel data models. Journal of Econometrics, 87(1), 115-143.

Bradley, M., Jarrell, G. A., \& Kim, E. (1984). On the existence of an optimal capital structure: Theory and evidence. The Journal of Finance, 39(3), 857-878.

Byoun, S. (2008). How and when do firms adjust their capital structures toward targets? The Journal of Finance, 63(6), 3069-3096.

Campello, M., Graham, J. R., \& Harvey, C. R. (2010). The real effects of financial constraints: Evidence from a financial crisis. Journal of Financial Economics, 97(3), 470-487.

Cook, D. O., \& Tang, T. (2010). Macroeconomic conditions and capital structure adjustment speed. Journal of Corporate Finance, 16(1), 73-87.

DeAngelo, H., \& Masulis, R. W. (1980). Optimal capital structure under corporate and personal taxation. Journal of Financial Economics, 8(1), 3-29.

Demirguc-Kunt, A., Martinez Peria, M., \& Tressel, T. (2015). The impact of the global financial crisis on firms' capital structure. Policy Research Working Paper 7522, World Bank Group.

Demirhan, D. (2009). Sermaye yapısını etkileyen firmaya özgü faktörlerin analizi: IMKB hizmet firmaları üzerine bir uygulama. Ege Academik Bakıss, 9(2), 677-697. 
Denis, D. J., \& McKeon, S. B. (2012). Debt financing and financial flexibility evidence from proactive leverage increases. The Review of Financial Studies, 25(6), 1897-1929.

Fama, E. F., \& MacBeth, J. D. (1973). Risk, return, and equilibrium: Empirical tests. Journal of Political Economy, 81(3), 607-636.

Ferri, M. G., \& Jones, W. H. (1979). Determinants of financial structure: A new methodological approach. The Journal of Finance, 34(3), 631-644.

Fischer, E. O., Heinkel, R., \& Zechner, J. (1989). Dynamic capital structure choice: Theory and tests. The Journal of Finance, 44(1), 19-40.

Flannery, M. J., \& Rangan, K. P. (2006). Partial adjustment toward target capital structures. Journal of Financial Economics, 79(3), 469-506.

Frank, M. Z., \& Goyal, V. K. (2003). Testing the pecking order theory of capital structure. Journal of Financial Economics, 67(2), 217-248.

Gaud, P., Jani, E., Hoesli, M., \& Bender, A. (2005). The capital structure of Swiss companies: an empirical analysis using dynamic panel data. European Financial Management, 11(1), 51-69.

Getzmann, A., Lang, S., \& Spremann, K. (2014). Target capital structure and adjustment speed in Asia. Asia-Pacific Journal of Financial Studies, 43(1), 1-30.

Gupta, M. C. (1969). The effect of size, growth, and industry on the financial structure of manufacturing companies. The Journal of Finance, 24(3), 517-529.

Guler, O. G. D. S. (2010). İstanbul Menkul Kıymetler Borsasına (iMKB) kayıtlı küçük ve orta büyüklükteki işletmelerin (Kobi) sermaye yapıları üzerine bir uygulama. Süleyman Demirel Üniversitesi Iktisadi ve Idari Bilimler Fakültesi Dergisi, 15(3), 353-371.

Guner, A. (2016). The determinants of capital structure decisions: New evidence from Turkish companies. Procedia Economics and Finance, 38, 84-89.

Haas, R., \& Peeters, M. (2006). The dynamic adjustment towards target capital structures of firms in transition economies. Economics of Transition, 14(1), 133-169.

Harford, J., Klasa, S., \& Walcott, N. (2009). Do firms have leverage targets? Evidence from acquisitions. Journal of Financial Economics, 93(1), 1-14.

Hovakimian, A. (2004). The role of target leverage in security issues and repurchases. The Journal of Business, 77(4), 1041-1072.

Karadeniz, E., Yilmaz Kandir, S., Balcilar, M., \& Beyazit Onal, Y. (2009). Determinants of capital structure: Evidence from Turkish lodging companies. International Journal of Contemporary Hospitality Management, 21(5), 594-609.

Kayhan, A., \& Titman, S. (2007). Firms' histories and their capital structures. Journal of Financial Economics, 83(1), 1-32.

Koksal, B., \& Orman, C. (2015). Determinants of capital structure: Evidence from a major developing economy. Small Business Economics, 44(2), 255-282.

Korajczyk, R. A., \& Levy, A. (2003). Capital structure choice: macroeconomic conditions and financial constraints. Journal of Financial Economics, 68(1), 75-109.

Kraus, A., \& Litzenberger, R. H. (1973). A state-preference model of optimal financial leverage. The Journal of Finance, 28(4), 911-922.

Krishnaswami, S., Spindt, P. A., \& Subramaniam, V. (1999). Information asymmetry, monitoring, and the placement structure of corporate debt. Journal of Financial Economics, 51(3), 407-434.

Masulis, R. W. (1980). The effects of capital structure change on security prices: A study of exchange offers. Journal of Financial Economics, 8(2), 139-178.

Miller, M. H. (1977). Debt and taxes. The Journal of Finance, 32(2), 261-275.

Modigliani, F., \& Miller, M. H. (1958). The cost of capital, corporation finance and the theory of investment. The American Economic Review, 48(3), 261-297.

Modigliani, F., \& Miller, M. H. (1963). Corporate income taxes and the cost of capital: a correction. The American Economic Review, 53(3), 433-443.

Myers, S. C. (1984). The capital structure puzzle. The Journal of Finance, 39(3), 574-592.

Myers, S. C., \& Majluf, N. S. (1984). Corporate financing and investment decisions when firms have information that investors do not have. Journal of Financial Economics, 13(2), 187-221. 
Ovtchinnikov, A. V. (2010). Capital structure decisions: Evidence from deregulated industries. Journal of Financial Economics, 95(2), 249-274.

Ozkan, A. (2001). Determinants of capital structure and adjustment to long run target: Evidence from UK company panel data. Journal of Business Finance \& Accounting, 28(1-2), 175-198.

Oztekin, O., \& Flannery, M. J. (2012). Institutional determinants of capital structure adjustment speeds. Journal of Financial Economics, 103(1), 88-112.

Porta, R. L., Lopez-de-Silanes, F., Shleifer, A., \& Vishny, R. W. (1998). Law and finance. Journal of Political Economy, 106(6), 1113-1155.

Rajan, R. G., \& Zingales, L. (1995). What do we know about capital structure? Some evidence from international data. The Journal of Finance, 50(5), 1421-1460.

Roden, D. M., \& Lewellen, W. G. (1995). Corporate capital structure decisions: Evidence from leveraged buyouts. Financial Management, 76-87.

Sayilgan, G., Karabacak, H., \& Kucukkocaoglu, G. (2006). The firm-specific determinants of corporate capital structure: Evidence from Turkish panel data. Investment Management and Financial Innovations, 3(3), 125-139.

Shyam-Sunder, L., \& Myers, S. C. (1999). Testing static tradeoff against pecking order models of capital structure. Journal of Financial Economics, 51(2), 219-244.

Smith Jr, C. W. (1986). Investment banking and the capital acquisition process. Journal of Financial Economics, 15(1-2), 3-29.

Song, K. R., \& Lee, Y. (2012). Long-term effects of a financial crisis: Evidence from cash holdings of East Asian firms. Journal of Financial and Quantitative Analysis, 47(3), 617-641.

Titman, S. (1984). The effect of capital structure on a firm's liquidation decision. Journal of Financial Economics, 13(1), 137-151.

Titman, S., \& Wessels, R. (1988). The determinants of capital structure choice. The Journal of Finance, 43(1), 1-19. 
This Page Intentionally Left Blank 